\title{
Effect of an alkaloidal fraction of Tabernaemontana elegans (Stapf.) on selected micro-organisms
}

\author{
CA Pallant, AD Cromarty, V Steenkamp* \\ Department of Pharmacology, Faculty of Health Sciences, University of Pretoria, \\ South Africa
}

* Address and correspondence for reprints:

Prof. V Steenkamp

Department of Pharmacology

Faculty of Health Sciences

University of Pretoria

Private Bag X323

Arcadia

South Africa, 0007

Tel: +27123192547

Fax: +27 123192411 


\section{Abstract}

Ethnopharmacological relevance: Bacterial infections remain a significant threat to human health. Due to the emergence of widespread antibiotic resistance, development of novel antibiotics is required in order to ensure that effective treatment remains available. There are several reports on the ethnomedical use of Tabernaemontana elegans pertaining to antibacterial activity.

Aim of the study: The aim of this study was to isolate and identify the fraction responsible for the antimicrobial activity in T. elegans (Stapf.) root extracts.

Materials and methods: The active fraction was characterised by thin layer chromatography (TLC) and gas chromatography - mass spectrometry (GC-MS). Antibacterial activity was determined using the broth micro-dilution assay and antimycobacterial activity using the BACTEC radiometric assay. Cytotoxicity of the crude extract and fractions was assessed against primary cell cultures; lymphocytes and fibroblasts; as well as a hepatocarcinoma (HepG2) and macrophage (THP-1) cell line using the Neutral Red uptake and MTT assays.

Results: The crude root extracts were found to contain a high concentration of alkaloids (1.2\% w/w). GC-MS analysis identified the indole alkaloids, voacangine and dregamine, as major components. Antibacterial activity was limited to the Grampositive bacteria and Mycobacterium species, with MIC values in the range of $64-$ $256 \mu \mathrm{g} / \mathrm{ml}$. When combined with antibiotics, additive antibacterial effects were observed. Marked cytotoxicity to all cell lines tested was evident in the MTT and Neutral Red uptake assays, with $\mathrm{IC}_{50}$ values $<9.81 \mu \mathrm{g} / \mathrm{ml}$. 
Conclusions: This study confirms the antibacterial activity of $T$. elegans and supports its potential for being investigated further for the development of a novel antibacterial compound.

\section{Keywords:}

Antibacterial; indole alkaloids; methicillin-resistant Staphylococcus aureus; mycobacteria; respiratory; Tabernaemontana elegans; Tuberculosis

\section{List of Abbreviations}

AF

alkaloidal fraction

CFU colony forming units

cps counts per second

FIC fractional inhibitory concentration

GC-MS gas chromatography - mass spectrometry

LLE liquid-liquid extraction

MRSA methicillin-resistant Staphylococcus aureus

MBC minimum bactericidal concentration

MIC minimum inhibitory concentration

M/XDR-TB multi/extensively drug-resistant tuberculosis

NIST National Institute of Standards and Technology

PHA phytohaematoglutinin

PMA phorbol 12-myristate 13-acetate

TB tuberculosis

TLC thin layer chromatography

UV ultraviolet

VISA vancomycin-intermediate Staphylococcus aureus

VRSA vancomycin-resistant Staphylococcus aureus 


\section{Introduction}

A crisis of antibiotic resistance is looming globally. Resistance mechanisms have been identified for all classes of antibiotics available (Gold and Moellering, 1996) and in certain bacterial strains, multiple resistance mechanisms have been acquired (Hawkey and Jones, 2009). Infections caused by such strains are difficult and more costly to treat, and are associated with higher incidences of mortality and morbidity, clearly demonstrating the clinical impact of antibiotic resistance (Sefton, 2002).

Tuberculosis (TB) is a bacterial infection where new antibacterial drugs are desperately needed. Infection with Mycobacterium tuberculosis occurs every second (World Health Organisation, 2010a), and in 2009, it was estimated that there were 11 million cases of TB globally, resulting in 1.3 million deaths annually. Cases of multidrug resistant tuberculosis (MDR-TB), defined as $M$. tuberculosis infections that are resistant to treatment with isoniazid and rifampicin, are rising, with approximately half a million cases reported in 2008 (World Health Organisation, 2010b). The treatment of MDR-TB requires the use of second-line anti-tuberculosis agents, which are 10 times more expensive due to the longer duration of treatment required (Dorman and Chaisson, 2007), and is associated with greater toxicity (Johnson et al., 2006).The implications of the multi/extensively drug-resistant tuberculosis (M/XDR-TB) for public health are not fully known, but as the treatment of TB intensifies globally, the proportion of $M$. tuberculosis strains that are drug-resistant is bound to rise. This is especially true in high-burden, low-resource settings, where the majority of M/XDR-TB cases are found. 
It has been over 60 years since the first strains of methicillin-resistant Staphylococcus aureus (MRSA) were identified. Previously, the strains of MRSA were overwhelmingly associated with nosocomial settings (Salgado et al., 2003), however, the rapid evolution of MRSA has garnered it the ability to cause community-acquired infections in previously-healthy young adults and children. In case studies of patients with invasive (i.e. non skin and soft-tissue) communityacquired MRSA infections, mortality rates have been found to be as high as $35 \%$ (Hageman et al., 2006). Vancomycin remains the agent of choice in serious MRSA infections (Gemmel et al., 2006). This reliance on vancomycin for the treatment of serious MRSA infections is not a sustainable situation, as vancomycin-intermediate and vancomycin-resistant Staphylococcus aureus (VISA and VRSA, respectively) strains have been reported in the literature (Nannini et al., 2010). These infections, without the development of new antibiotics, will represent a growing source of mortality in the years to come.

Tabernaemontana elgans (Stapf.) (syn. Conopharyngia elegans (Stapf.)), a member of the Apocynaceae family, is a small tree found in evergreen river fringes at low altitudes and in coastal scrub forest (Coats Palgrave et al., 2003). It is known in English as the toad tree due to the brown, wart-like skin of its fruit. There are several reports of the ethnomedical use of $T$. elegans pertaining to antibacterial activity: a root decoction is applied as a wash to wounds, and drunk for pulmonary diseases and chest pains by the VhaVenda (Arnold and Gulumian, 1984) and Zulu (Watt and Breyer-Brandwijk, 1962) people of South Africa. Other ethnomedical usages include treatment of heart diseases with the seeds, stem-bark and roots, the root-bark and 
fruits for cancer treatment, and a root decoction is said to have aphrodisiac properties (Neuwinger, 1966).

$T$. elegans has previously been identified as having antibacterial activity against $S$. aureus and antimycobacterial activity against $M$. smegmatis (Pallant and Steenkamp, 2008), as well as anti-fungal activity against Candida albicans (Steenkamp et al., 2007). An earlier study identified T. elegans as one of eight Tabernaemontana species possessing antibacterial activity against Gram-positive bacteria (Van Beek et al., 1984). In these studies, the compound(s) responsible for the reported biological activity was not identified.

Previous phytochemical research has shown $T$. elegans to be particularly rich in monoterpenoidindole alkaloids (Gabetta et al., 1975; Bombardelli et al., 1976; Danieli et al., 1980; Van der Heijden et al., 1986). These alkaloids, which are structurally diverse, are commonly found in many members of the genus and are considered chemotaxonomically important (Zhu et al., 1990). To date, over 300 of these alkaloids have been isolated (Cardoso et al., 1998).

The biological activity of $T$. elegans, especially in terms of antibacterial activity, which has thus far been reported for crude extracts, remains less thoroughly investigated. Due to the clear need for new agents which may be used for the treatment of tuberculosis and other bacterial infections, this study was aimed at isolating the active fraction responsible for the antibacterial activity of this plant. 


\section{Materials and methods}

\subsection{Plant material and extraction procedures}

Roots of Tabernaemontana elegans (Stapf.) were collected from the Venda region of Limpopo, South Africa. The plant material was authenticated and a voucher specimen (NH 1920) deposited at the Soutpanbergensis Herbarium (Makhado, Limpopo). Powdered root was extracted by maceration in ethanol at a ratio of $100 \mathrm{~g}$ plant material to $1 \mathrm{I}$ solvent. The flask was placed in an ultrasonic bath for $1 \mathrm{~h}$, then left to stand overnight at ambient temperature. The extract was centrifuged $(1000 \mathrm{~g}, 5$ min) and vacuum-filtered through $0.44 \mu \mathrm{m}$ filters. The plant material was macerated twice under similar conditions and the three extracts combined.

\subsubsection{Crude extract}

The ethanol maceration was concentrated to dryness with a rotary evaporator at $40^{\circ} \mathrm{C}$ under reduced pressure. Liquid-liquid extraction (LLE) was performed using distilled water and hexane. The aqueous fraction was lyophilized and stored at $4^{\circ} \mathrm{C}$ in a desiccator until use.

\subsubsection{Alkaloidal fraction}

An alkaloidal fraction (AF) was obtained by an acid-base extraction method. An aliquot of the ethanol maceration was partitioned between $2 \%$ acetic acid and hexane, with the hexane fraction being discarded. The aqueous layer was adjusted 
to $\mathrm{pH} 10$ with ammonia in order to precipitate the alkaloids present. Using LLE, the precipitated alkaloids were collected into chloroform and dried using sodium sulphate, (1.2\% dry weight/weight). The $\mathrm{AF}$ was dried at $40^{\circ} \mathrm{C}$ and reconstituted in ethanol to a concentration of $100 \mathrm{mg} / \mathrm{ml}$ and stored at $-20^{\circ} \mathrm{C}$ until use.

\subsection{Chemical characterisation}

\subsubsection{Phytochemical screening of the crude extract}

Compounds in the crude extract were separated on silica TLC plates $(10 \times 10 \mathrm{~cm})$ using a mobile phase of 17:2:1 ethyl acetate:2-propanol:ammonia. Developed TLC plates were assessed for the presence of various phytochemical groups, by utilization of visible and ultraviolet (UV) light, in addition to various spray reagents (Stahl, 1969; Harborne, 1998) which were selected to visualise specific classes of compounds (alkaloids, coumarins, essential oils, flavonoids, phenols and sterols/steroids).

\subsubsection{Gas chromatography mass spectrometry (GC-MS) analysis of the alkaloidal} fraction

GC-MS analysis of the crude extract and alkaloidal fraction was performed using an Agilent 7890 GC-MS equipped with a DB5-MS column $(30 \mathrm{~m} \times 0.32 \mu \mathrm{m}$ i.d., film thickness $0.25 \mathrm{~mm}$, J\&W Scientific). Helium was used as the carrier gas at a 
constant flow, and the injection split ratio was 50:1. The injector temperature was $280^{\circ} \mathrm{C}$. Column temperature was programmed to rise from $80^{\circ} \mathrm{C}$ to $310^{\circ} \mathrm{C}$ at $10^{\circ} \mathrm{C} / \mathrm{min}$ for $23 \mathrm{~min}$, then maintained at $310^{\circ} \mathrm{C}$ for $7 \mathrm{~min}$ (Total run time $30 \mathrm{~min}$ ).

The acquisition mode selected for mass spectrometry was scan mode, with a scan range of $35-550 \mathrm{Da}$ and a threshold of 100 counts per second (cps). Solvent delay was 4 min. Quadrupole temperature was $150^{\circ} \mathrm{C}$, with the transfer line temperature set to $280^{\circ} \mathrm{C}$. GC and mass spectrometry parameters, data collection and analysis were performed by Agilent Chemstation. Identity of the compounds was determined using the National Institute of Standards and Technology (NIST) library.

\subsection{Anti-microbial assays}

\subsection{1 $\underline{\text { Micro-organisms }}$}

The crude extract and alkaloidal fraction were tested for antibacterial activity against the Gram-positive bacteria Bacillus subtilis (ATCC 6633), Enteroccocus faecalis (ATCC 29212) and Straphylococcus aureus (ATCC 12600), the mycobacteria M. tuberculosis $\mathrm{H}_{37} \mathrm{R}_{V}$ (ATCC 25177) and M. smegmatis (ATCC 14468), and the Gramnegative bacteria Escherichia coli (ATCC 35218), Klebsiella pneumoniae (ATCC 13883) and Pseudomonas aeruginosa (ATCC 9027). Samples were also tested against a clinical isolate of methicillin-resistant $S$. aureus (NHLS 363), obtained from the National Health Laboratory Service, Pretoria, and a clinical isolate of $M$. tuberculosis displaying resistance to isoniazid (MRC 3366), obtained from the Tuberculosis Unit, Medical Research Council, Pretoria. 
Microbial cultures were maintained on Lowenstein Jensen medium (M. tuberculosis), Mannitol Salt Agar (S. aureus), Mueller-Hinton agar supplemented with $5 \%$ sheep blood (E. faecalis, P. aeruginosa) and Nutrient agar (B. subtilis, E. coli, $K$. pneumoniae, M. smegmatis).

\subsubsection{Bacterial inocula}

Bacterial inocula for all micro-organisms apart from $M$. tuberculosis were prepared by transferring colonies from $24 \mathrm{~h}$, freshly prepared subcultures $(72 \mathrm{~h}$ subcultures in the case of M. smegmatis) to an aliquot of Mueller Hinton broth. Inocula were diluted with additional broth to a 0.5 McFarland turbidity standard, and then further diluted with liquid media to obtain a concentration of $5 \times 10^{5}$ colony forming units (CFU/mL).

Inocula of M. tuberculosis were prepared by transferring colonies from a culture to test tube containing sterile glass beads and diluting fluid (0.1\% Tween 20$)$. A homogeneous suspension was obtained by vortex mixing. After the large particles had settled, the supernatant was transferred to a test tube and adjusted to a 1

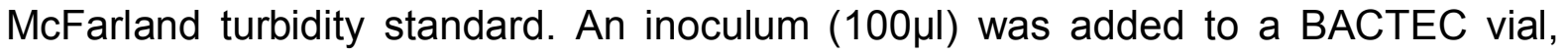
incubated at $37^{\circ} \mathrm{C}$, with Growth Index $(\mathrm{Gl})$ readings taken daily. Once the $\mathrm{Gl}$ reached $400-500$, contamination of the inoculum was assessed by overnight growth on blood agar. If free of contamination, the inocula were used on the BACTEC assay described below. 


\subsubsection{Broth micro-dilution assay}

Determination of the minimum inhibitory concentration (MIC) for the all the bacterial species, apart from the strains of $M$. tuberculosis, was performed using the broth micro-dilution assay (National Committee for Clinical Laboratory Standards, 2008).

Stock solutions of the test samples and antibiotic standards were prepared in distilled water. The concentrations of the stock solutions were $4.096 \mathrm{mg} / \mathrm{ml}$ for the crude extract, $2.048 \mathrm{mg} / \mathrm{ml}$ for the alkaloidal and basic fraction, $32 \mu \mathrm{g} / \mathrm{ml}$ for ampicillin and $2 \mu \mathrm{g} / \mathrm{ml}$ for ciprofloxacin. In order to increase the solubility of the alkaloidal fraction in distilled water, the stock solution was acidified to $\approx \mathrm{pH} 6.5$ with acetic acid. All stock solutions were kept at $-20^{\circ} \mathrm{C}$ until use.

Ampicillin and ciprofloxacin were serially diluted in the media and served as the positive control for the Gram-positive bacteria and Gram-negative bacteria and $M$. smegmatis, respectively. Wells containing $50 \mu \mathrm{l}$ of media without plant extracts or antibiotics were used as growth controls. Wells containing $100 \mu \mathrm{l}$ of medium served as the sterility control. Inocula $(50 \mu \mathrm{l})$ was added to the all wells except the sterility controls to give a final volume of $100 \mu$ before incubating at $37^{\circ} \mathrm{C}$ in an ambient atmosphere for $24 \mathrm{~h}$ (72 $\mathrm{h}$ in the case of M. smegmatis). The MIC was defined as the lowest concentration of the sample that was able to visibly inhibit the growth of the bacteria. 
From all wells that demonstrated no apparent bacterial growth, the entire well contents $(100 \mu \mathrm{l})$ were streaked in a straight line on a Mueller Hinton agar plate. After allowing the broth to dry, which prevented antibiotic carry-over, the plate was streaked to form a lawn of bacterial growth and incubated for $24 \mathrm{~h}$ at $37^{\circ} \mathrm{C}(72 \mathrm{~h}$ in the case of $M$. smegmatis). A 100-fold dilution of the starting inoculum was used to determine the starting colony count (Anhalt et al., 1980). The minimum bactericidal concentration $(\mathrm{MBC})$ was defined as the concentration of a compound or extract that resulted in $>99.9 \%$ killing of bacterium relative to the concentration of the bacterium present in the inoculum (National Committee for Clinical Laboratory Standards, 2008). Each assay was performed in triplicate and on at least three different occasions.

\subsubsection{BACTEC radiometric assay}

The BACTEC radiometric broth dilution assay was used to determine the MIC of the samples for the two strains of M. tuberculosis (Siddiqi et al., 1981). Starting concentrations were $1.052 \mathrm{mg} / \mathrm{ml}, 512 \mu \mathrm{g} / \mathrm{ml}$ and $0.1 \mu \mathrm{g} / \mathrm{ml}$ for the crude extract, alkaloidal fraction and isoniazid, respectively. Three vials were used as controls, two containing only medium and the vehicle, representing solvent controls, while the third contained only medium and was the growth control. From the BACTEC vial containing the inoculum of $M$. tuberculosis, $100 \mu \mathrm{l}$ was transferred to the vials containing the samples and the two solvent control vials. In the growth control vial, a 1:100 dilution of the inoculum was added, representing $1 \times 10^{3}-1 \times 10^{2} \mathrm{CFU} / \mathrm{ml}$, or $1 \%$ of the initial mycobacterial population. 
Inoculated vials were incubated at $37^{\circ} \mathrm{C}$, with each vial assayed at $24 \mathrm{~h}$ intervals until the growth control vial reached a GI of greater than 30 . The following day, final readings were taken and the $\Delta \mathrm{GI}$ determined for all samples. The MIC was defined as the lowest concentration of a sample for which the $\Delta \mathrm{GI}$ was less than the $\Delta \mathrm{GI}$ of the growth control. If the $\mathrm{GI}$ of the sample was greater than $100, M$. tuberculosis was deemed to be resistant to the sample, even if the $\Delta G$ I was less than that of the growth control.

\subsection{Synergistic antimicrobial activity assays}

Assessment of the synergistic activity between the alkaloidal fraction and the antibiotics utilized as controls for the broth micro-dilution assay was performed using a chequerboard synergy testing protocol (Bonapace et al., 2000). This was performed for all susceptible bacterial strains, however, the methodology was adapted for used in the BACTEC assay for M. tuberculosis.

A dilution series of the alkaloidal fraction and of the antibiotics was made up in Mueller Hinton broth, with the concentration range representing $1 / 8 \times \mathrm{MIC}-1 \times \mathrm{MIC}$ for the sample against the specific bacteria, as previously determined in the broth micro-dilution assay. 
In a four-by-four grid on a 96 well microtitre plate, $25 \mu \mathrm{l}$ of the dilution series of the alkaloidal fraction was added along the x-axis of the grid, while $25 \mu$ of the antibiotic dilution series was added to the y-axis of the grid. Wells containing $50 \mu \mathrm{l}$ of samplefree medium served as growth controls and wells containing $100 \mu \mathrm{l}$ of medium served as sterility controls. Each well containing $50 \mu \mathrm{l}$ of the alkaloidal fraction/antibiotic mixture was inoculated with $50 \mu$ of the bacterial inocula. The microtitre plates were incubated at $37^{\circ} \mathrm{C}$ in an ambient atmosphere for $24 \mathrm{~h}(72 \mathrm{~h}$ in the case of $M$. smegmatis).

For $M$. tuberculosis, BACTEC vials were arranged in a four-by-four grid, and $50 \mu \mathrm{l}$ of the alkaloidal fraction was added along the x-axis of the grid, while $50 \mu \mathrm{l}$ of the antibiotic dilution series was added to the $y$-axis of the grid. The rest of the BACTEC assay was performed as described above.

The mean fractional inhibitory concentration (FIC) was used to interpret the results of the chequerboard synergy assay. The FIC was defined as:

$\mathrm{FIC}=\underline{\text { MIC of drug } \mathrm{A} \text { in combination }}+\underline{\text { MIC of drug } \mathrm{B} \text { in combination }}$

MIC of drug A alone MIC of drug B alone

The FIC was calculated for each sample indicating no growth along the growth/inhibition interface of the grid. Synergism between the samples was defined as a mean FIC of $\leq 0.5$, additivity as a value of $>0.5-4$ and antagonism as a value 
of $>4$ (Bonapace et al., 2000). Each four-by-four grid was repeated in triplicate on at least three different occasions.

\subsection{Cytotoxicity assays}

Stock solutions of the test reagents were prepared by re-constitution in distilled water. The concentrations of the stock solutions were $410 \mu \mathrm{g} / \mathrm{ml}$ for the crude extract and the basic aqueous fraction, $205 \mu \mathrm{g} / \mathrm{ml}$ for the alkaloidal fraction, and $1 \%(\mathrm{w} / \mathrm{v})$ for saponin. In order to increase the solubility of the alkaloidal fraction in distilled water, the stock solution was acidified to $\mathrm{pH} 6.5$ with acetic acid. All stock solutions were kept at $-20^{\circ} \mathrm{C}$ until use.

\subsubsection{Cell lines}

Cytotoxicity of the crude ethanol extract and alkaloidal fraction was determined against normal human dermal fibroblasts (Southern Medical, SA), human lymphocytes, HepG2 hepatocytes (ATCC HB 8065) and THP1 macrophages (ATCC TIB 2.2).

Human lymphocytes were isolated from whole blood (Anderson et al., 1993) obtained after ethical approval (University of Pretoria) from healthy volunteers. The media and cell concentrations used in the assays were DMEM-F12 and $5 \times 10^{4}$ cells/ml, RMPI-1640 and $2 \times 10^{6}$ cells $/ \mathrm{ml}$, EMEM and $5 \times 10^{5}$ cells $/ \mathrm{ml}$, THP-medium 
and $1 \times 10^{5}$ cells $/ \mathrm{ml}$ for the normal human dermal fibroblasts, human lymphocytes, HepG2 and THP-1 cells, respectively. All media was supplemented with $10 \%$ foetal calf serum. To each well of a microtitre plate, $100 \mu$ of the cell suspension was added. For the fibroblasts and hepatocytes, an additional $80 \mu$ of FCSsupplemented medium was added to the microtitre plates which were incubated for $24 \mathrm{~h}$ at $37^{\circ} \mathrm{C}$ in a humidified atmosphere of $5 \% \mathrm{CO}_{2}$ to allow for cellular adhesion. Lymphocytes $(100 \mu \mathrm{l})$ were added to each well of a microtitre, together with $60 \mu \mathrm{l}$ of medium. Following $1 \mathrm{~h}$ incubation at $37^{\circ} \mathrm{C}$ in a humidified atmosphere of $5 \% \mathrm{CO}_{2}, 20$ $\mu \mathrm{l}$ of a $5 \mu \mathrm{g} / \mathrm{ml}$ solution of phytohaematoglutinin (PHA) in medium was added to selected microtitre plates to produce populations of stimulated lymphocytes, while other microtitre plates received a further $20 \mu \mathrm{l}$ of medium and represented resting lymphocytes. For the THP-1 cells, $100 \mu \mathrm{l}$ of the cell suspension and $80 \mu \mathrm{l}$ THP medium was plated into the wells of a 96-well microtitre plate. Plates were incubated for $1 \mathrm{~h}$ at $37^{\circ} \mathrm{C}$ in a humidified atmosphere of $5 \% \mathrm{CO}_{2}$. Differentiation of the THP-1 monocytes into macrophages was induced by the addition of $20 \mu \mathrm{l}$ of a $0.1 \mu \mathrm{g} / \mathrm{ml}$ solution of phorbol 12-myristate 13-acetate (PMA) in THP medium, followed by a further $48 \mathrm{~h}$ incubation period.

\subsubsection{Cytotoxicity assays}

Two-fold serial dilutions of the crude extract $(1.6-204.8 \mu \mathrm{g} / \mathrm{ml})$, alkaloidal fraction $(0.1-12.8 \mu \mathrm{g} / \mathrm{ml})$ and aqueous fraction $(3.2-410 \mu \mathrm{g} / \mathrm{ml})$ were prepared. Saponin $(0.0008-0.1 \% \mathrm{w} / \mathrm{v})$, served as the positive control. Each well containing cells received either $20 \mu \mathrm{l}$ of the sample or for the growth controls, $20 \mu \mathrm{l}$ of medium. The cells were incubated for $72 \mathrm{~h}$ at $37^{\circ} \mathrm{C}$ in a humidified atmosphere of $5 \% \mathrm{CO}_{2}$ before 
the cytotoxicity assays were conducted. The MTT assay was performed as described by Mosmann (1983), and the Neutral Red uptake assay as described by Borenfreund and Puerner (1986). All assays were conducted in triplicate, on three different days.

The concentration of sample that prevented the survival of $50 \%$ of the cell population $\left(\mathrm{IC}_{50}\right)$ was determined by non-linear regression from optical density measurements. Sample optical density values were converted to a percentage of the average growth of control wells. Non-linear regression, using a sigmoidal dose-response curve model with a bottom constraint of 0 , was performed using GraphPad Prism 4.0 software.

\section{Results and discussion}

Phytochemical screening of the crude extract indicated the presence of: alkaloids, amines, essentials oils, phenols and steroids/sterols. Phytochemical screening of other Tabernaemontana species support these findings. The presence of triterpenes/triterpenoids and steroids (Cardoso et al., 1998), flavonoids, plenylpropanoids and phenolic acids (Chattipakorn et al., 2007) and phytosterols (Mederios et al., 2001) has been reported.

GC-MS analysis of the crude extract and alkaloidal fraction indicated the presence of two major compounds that together accounted for more than $75 \%$ of all the detected 
compounds. These compounds, identified with a greater than $90 \%$ certainty by comparison to the NIST database, were the indole alkaloids, dregamine [20 $, 19,20$ dihydro-3-oxoVobasan-17-oic acid methyl ester] and voacangine methoxyibogamine-18-carboxylic acid methyl ester) (Fig. 1). Dregamine has been reported to be present in other species of Tabernaemontana, and has previously been isolated from T. elegans (Gabetta et al., 1975; Van der Heijden et al., 1986). The presence of voacangine in various Tabernaemontana species is also known (Kingston, 1978).

The MICs and MBCs obtained in the broth micro-dilution assay for the crude ethanolic extract and alkaloidal fraction of $T$. elegans, as well as the antibiotic controls, are reported in Table 1. The antimicrobial activity of the crude ethanolic extract was limited to Gram-positive bacteria and the mycobacteria. B. subtilis demonstrated the highest susceptibility to the antimicrobial-effects of the crude extract.

These results are supported by reports of antibacterial properties for the ethanolic extract of $T$. elegans, against B. subtilis and S. aureus (Van Beek et al., 1984). This study indicated antimycobacterial activity against $M$. smegmatis and M. tuberculosis, confirming a previous report of antimycobacterial activity against $M$. smegmatis (Pallant and Steenkamp, 2008). 
The alkaloidal fraction demonstrated antibacterial activity against the same organisms as that of the crude extract, but at a significantly lower concentration (Table 1). These results support the hypothesis that the alkaloids enriched in the alkaloid subfraction, are primarily responsible for the antimicrobial activity of $T$. elegans. The presence of drug resistance in the bacteria from clinical isolates tested in this study did not have an effect on the susceptibility of the bacteria to the crude extract or the alkaloidal fraction. This effect has been reported for another species of Tabernaemontana (Ruttoh et al., 2009).

The alkaloidal fraction of $T$. catharinensis has known activity against 3 species of mycobacteria, as well as Gram-positive and Gram-negative bacteria (Pereira et al., 2005). Isolated alkaloids from various Tabernaemontana species: conoduramine, conodurine, and voacamine, possess strong antibacterial activity against Grampositive bacteria (Van Beek et al., 1984; 1985). The alkaloids ibogamine and voacangine have proven antimycobacterial activity (Rastogi et al., 1998). None of these compounds, however, have been previously identified in $T$. elegans, suggesting that the pharmacophore responsible for the antibacterial activity may be common to a number of alkaloids in this genus.

All MBC values of the crude extract and alkaloidal fraction were within two serial dilutions of the respective MICs obtained for the bacterium, indicating that the antibacterial alkaloids of $T$. elegans are bacteriocidal. 
The combination of the alkaloidal fraction and either ampicillin for Gram-positive bacteria, ciprofloxacin for M. smegmatis or isoniazid for M. tuberculosis, reduced the required concentration of both agents to inhibit the growth of all bacteria assayed indicating additive activity (FIC 0.76-1.26).

The combination of $16 \mu \mathrm{g} / \mathrm{ml}(1 / 2 \times \mathrm{MIC})$ of the alkaloidal fraction and $0.06 \mu \mathrm{g} / \mathrm{ml}$ ampicillin produced an inhibitory effect on growth of the methicillin-resistant strain of S. aureus. The controls for the experiment, which consisted of either the alkaloidal fraction or ampicillin at the above concentrations alone, did not produce the same effect. This effect was not seen, however, in isoniazid-resistant $M$. tuberculosis, where a mixture of $16 \mu \mathrm{g} / \mathrm{ml}$ of the alkaloidal fraction and $0.1 \mu \mathrm{g} / \mathrm{ml}$ of isoniazid failed to inhibit the growth of the mycobacteria. The results obtained in this study indicate that the alkaloids present in $T$. elegans possess additive activity when combined with ampicillin or isoniazid, and that these alkaloids may be able to reverse resistance acquired against ampicillin. Furthermore, this finding implicates that the mechanism(s) of action responsible for the antibacterial activity of the alkaloidal fraction differs from those employed by antibiotics used in the assay. No reports could be found in the literature of other studies assessing the synergistic antibacterial effects of extracts or alkaloids of the Tabernaemontana genus in combination with antibiotics.

The effects of the crude ethanolic extract and the alkaloidal fraction of the roots of $T$. elegans on cell viability for the cell lines and primary cultures are presented in Table 2. The $I_{50}$ values for the crude ethanolic extract in both assays ranged from 1.93 
$\mu \mathrm{g} / \mathrm{ml}-19.27 \mu \mathrm{g} / \mathrm{ml}$ and showed dose-dependent response curves. Smaller $\mathrm{IC}_{50}$ values were obtained for the alkaloidal fraction, ranging from $1.11 \mu \mathrm{g} / \mathrm{ml}-9.81 \mu \mathrm{g} / \mathrm{ml}$. The lower $I C_{50}$ values obtained for the alkaloidal fraction, combined with the nontoxicity of the basic fraction, demonstrate that it is primarily the indole alkaloids of $T$. elegans that are responsible for the cytotoxicity observed in the crude extract.

Previous research on crude extracts of Tabernaemontana species has shown conflicting evidence of cytotoxicity. An aqueous extract of $T$. elegans demonstrated weak toxicity to human lymphocytes, with $\mathrm{IC}_{50}$ concentrations ranging between 90 $160 \mu \mathrm{g} / \mathrm{ml}$ (Pallant and Steenkamp, 2008). The earliest investigation of the cytotoxic effects of Tabernaemontana species showed that an aqueous methanolic extract of T. arborea possessed an $\mathrm{IC}_{50}$ of $8 \mu \mathrm{g} / \mathrm{ml}$ against P-388 cells (murine lymphocytic leukaemia) (Kingston et al., 1978). Methanolic and dichloromethane root extracts of T. divaricata were were found to be cytotoxic in COR L23 (human non-small cell lung cancer) and MCF7 (human breast adenocarinoma) cell lines, however, the aqueous extract did not produce an effect even at the highest concentration tested $(>25$ $\mu \mathrm{g} / \mathrm{ml}$ ) (Lee and Houghton, 2005). Another study on T. divaricata confirmed these results (Thind et al., 2008). On the contrary, a methanol extract of $T$. divaricata had no effect on resting human mesangial cells (Kuo et al., 1999). An ethyl acetate extract of the stem bark of $T$. laeta, and leaf extracts of $T$. amydalifolia exhibited no cytotoxicity $\left(\mathrm{IC}_{50}>20 \mu \mathrm{g} / \mathrm{ml}\right)$ in a $\mathrm{KB}$ human oral epidermoid carcinoma cell line (You et al, 1994; Ankli et al., 2002). A methanol extract of the leaves of T.obliqua was reported to have cytotoxic effects against promonocytic U937 cells, however, the $\mathrm{IC}_{50}$ value $(231.6 \mu \mathrm{g} / \mathrm{ml} \pm 2.7 \mu \mathrm{g} / \mathrm{ml})$ provided is substantially higher than what is deemed to be physiologically significant (Weniger et al., 2001). 
Several possible explanations exist for the lack of cytotoxicity activity reported in some of the crude extracts. It may be related to factors influencing the concentration of the alkaloids in the plant, such as pre-cursor availability (Dagnino et al., 1995; Lucumi et al., 2001), microbial attack (Fulton et al., 1994), or other environmental stressors, and factors influencing the concentration of alkaloids in the crude extract, such as plant part as well as the method of extraction and solvent system selected for extraction (Pereira et al., 2004).

From the literature, more than 40 isolated Tabernaemontana alkaloids have been assayed for cytotoxicity (Pallant, 2010). The majority of these alkaloids have $I_{50}$ values below $20 \mu \mathrm{g} / \mathrm{ml}$, indicating significant cytotoxic effects regardless of the type of cell or the cytotoxicity assay employed. Regarding the two alkaloids identified in this study, cytotoxicity has been reported for voacangine (Kingston, 1978; Chaturvedula et al., 2003). Furthermore, two alkaloids previously isolated from $T$. elegans, conoduramine and isovoacangine, have also been associated with cytotoxic activity. The cytotoxicity of the alkaloidal fraction of $T$. elegans may potentially be ascribed to the presence of these alkaloids.

\section{Conclusions}

The crude extract and the alkaloidal subfraction possessed significant antibacterial activity (MIC $\leq 256 \mu \mathrm{g} / \mathrm{ml}$ ) against the Gram-positive bacteria and mycobacteria, but did not influence the viability of the Gram-negative bacteria. This study leads support 
to the ethnomedical usage of $T$. elegans for the treatment of respiratory tract infections, and may indicate a potential future source of antibacterial molecules.

\section{Acknowledgements}

Funding was received from the National Research Foundation. The Medical Research Council and the National Health Laboratory Services are thanked for providing the clinical isolates of Mycobacterium tuberculosis and Staphylococcus aureus, respectively. 


\section{References}

Anderson, R., Smit, M.J., Van Rensberg, C.E.J., 1993. Lysophospholipid-mediated inhibition of $\mathrm{Na}+, \mathrm{K}(+)$-adenosine triphosphatase is a possible mechanism of the immunosuppressive activity of cyclosporine A. Molecular Pharmacology 44, 605 619.

Anhalt, J.P., Sabath, L.D., Barry, A.L., 1980. $3^{\text {rd }}$ edition. In: Lennette, E.H., Balows, A., Hausler, W.J. Jr. (Eds), Manual of clinical microbiology. American Society for Microbiology, Washington D.C., pp.453-458.

Ankli, A., Heinrich, M., Bork, P., Wolfram, L., Bauerfeind, P., Brun, R., Schmid C., Weiss C., Bruggisser R., Gertsch J., Wasescha M., Sticher O., 2002. Yucatec Mayan medicinal plants: evaluation based on indigenous uses. Journal of Ethnopharmacology 79, $43-52$.

Arnold, H.J., Gulumian, M., 1984. Pharmacopoeia of traditional medicine in Venda. Journal of Ethnopharmacology 12, $35-74$.

Bombardelli, E., Bonati, A., Gabetta, B., Martinelli, E.M., Mustich, G., Danieli, B., 1976. Structures of tabernaelegantines $A-D$ and tabernaelegantinines $A$ and $B$, new 
indole alkaloids from Tabernaemontana elegans. Journal of the Chemical Society, Perkin Transactions 13, $1432-1438$.

Bonapace, C.R., White, R.L., Friedrich, L.V., Bosso, J.A., 2000. Evaluation of the antibiotic synergy against Acinetobacter baumanii: A comparison with E-test, timekill, and checkerboard methods. Diagnostic Microbiology and Infectious Disease 38, $43-50$.

Borenfreund, E., Puerner, J.A., 1986. Cytotoxicity of metals, metal-metal and metal chelator combinations assays in vitro. Toxicology 39, $121-134$.

Cardoso, C.A.L., Vilegas, W., Honda, N.K., 1998. Qualitative determination of indole alkaloids, triterpenoids and steroids of Tabernaemontana hilariana. Journal of Chromatography A 808, $264-268$.

Chattipakorn, S., Pongpanparadorn, A., Pratchayasakul, W., Pongchaidacha, A., Ingkaninan, K., Chattipakorn, N., 2007.Tabernaemontana divaricata extracts inhibits neuronal acetylcholinesterase activity in rats. Journal of Ethnopharmacology 110, 61 -68 . 
Chaturvedula, V.S.P., Sprague, S., Schilling, J.K., Kingston, D.G.I., 2003. New cytotoxic indole alkaloids from Tabernaemontana calcarea from the Madagascar rainforest. Journal of Natural Products 66, $528-531$.

Coats Palgrave, K.C., Drummond, R.B., Moll, E.J., Coats Palgrave, M., 2003. Trees of Southern Africa, $3^{\text {rd }}$ Edition. New Holland Publishers, Cape Town.

Dagnino, D., Schripsema, J., Verpoorte, R., 1995. Terpenoidindole alkaloid biosynthesis and enzyme activities in two cell lines of Tabernaemontana divaricata. Phytochemistry $39,341-349$.

Danieli, B., Palmisano, G., Gabetta, B., Martinelli, E.M., 1980. Tabernaelegantinines C and D, two new bisindole alkaloids containing a cyano group from Tabernaemontana elegans Stapf. Part 2. Journal of the Chemical Society, Perkin Transactions 1(2), $601-606$.

Dorman, S.E., Chaisson, R.E., 2007. From magic bullets back to the Magic Mountain: the rise of extensively drug-resistant tuberculosis. Nature Medicine 13, $295-298$. 
Fulton, D.C., Kroon, P.A., Threlfall, D.R., 1994. Enzymological aspects of the redirection of terpenoid biosynthesis in elicitor-treated cultures of Tabernaemontana divaricata. Phytochemistry 35, 1183 - 1186.

Gabetta, B., Martinelli, E.M., Mustich, G., 1975. Plants of Mozambique. VII. Alkaloids of Tabernaemontana elegans. Fitoterapia 46, 195 - 198.

Gemmel, C.G., Edwards, D.I., Fraise, A.P., Gould, F.K., Ridgway, G.L., Warren, R.E., 2006. Guidelines for the prophylaxis and treatment of methicillin-resistant Staphylococcus aureus (MRSA) infections in the UK. Journal of Antimicrobial Chemotherapy 57, $589-608$.

Gold, H.S., Moellering, R.C., 1996. Antimicrobial-drug resistance. New England Journal of Medicine 355, $1445-1454$.

Hageman, J.C., Uyeki, T.M., Francis, J.S., Jernigan, D.B., Wheeler, J.G., Bridges C.B,Barenkamp S.J., Sievert, D.M., Srinivasan, A., Doherty, M.C., McDougal, L.K., Killgore, G.E., Lopatin, U.A., Coffman, R., MacDonald, J.K., McAllister, S.K., Fosheim, G.E., Patel, J.B., McDonald, L.C., 2006. Severe community-acquired pneumonia due to Staphylococcus aureus, 2003-04 influenza season. Emerging Infectious Disease 12, 894-899. 
Harborne, J.B., 1998. Phytochemical methods. $3^{\text {rd }}$ Edition, Chapman \& Hall, London.

Hawkey, P.M., Jones, A.M., 2009. The changing epidemiology of resistance. Journal of Antimicrobial Chemotherapy 64 Suppl.1, i3 - i10.

Johnson, R., Streicher, E.M., Louw, G.E., Warren, R.M., van Helden, P.D., Victor, T.C., 2006. Drug resistance in Mycobacterium tuberculosis. Current Issues in Molecular Biology 8, $97-112$.

Kingston, D.G.I., Gerhard, B.B., lonescu, F., Mangino, M.M., Sami, S.M., 1978. Plant anticancer agents V: New bisindole alkaloids from Tabernaemontana johnstonii stem bark. Journal of Pharmaceutical Sciences 67, $249-251$.

Kingston, D.G.I., 1978. Plant anticancer agents VI: Isolation of voacangine, voacamine, and epivoacorine from Tabernaemontana arborea sap. Journal of Pharmaceutical Sciences 67, $271-272$.

Kuo, Y.C., Sun, C.M., Tsai, W.J., Ou J.C., Chen, W.P., Lin, C.Y., 1999. Blocking of cell proliferation, cytokine production and gene expression following administration of Chinese herbs in human mesangial cells. Life Science. 64, $2089-2099$. 
Lee, C.C., Houghton, P., 2005. Cytotoxicity of plants from Malaysia and Thailand used traditionally to treat cancer. Journal of Ethnopharmacology 10, $237-243$.

Lucumi, E., Luczkiewicz, M., Vera, A., Hallard, R., Van der Heijden, R., Verpoorte, R., 2001. Alkaloid formation in cell suspension cultures of Tabernaemontana divaricate after feeding of tryptamine and loganin. Biotechnology Annual Review 23, $1961-1966$.

Mederios, W.L.B., Vieira, I.J.C., Mathias, L., Braz-Filho, R., Schripsema, J., 2001. A new natural quaternary indole alkaloid isolated from Tabernaemontana laeta Mart. (Apocynaceae). Journal of the Brazilian Chemical Society 12, $367-372$.

Mosmann, T., 1983. Rapid colorimetric assay for cellular growth and survival: Application to proliferation and cytotoxicity assays. Journal of Immunological Methods 65, $55-63$.

Nannini, E., Murray, B.E., Arias, C.A., 2010. Resistance or decreased susceptibility to glycopeptides, daptomycin and linezolid in methicillin-resistant Staphylococcus aureus. Current Opinion in Pharmacology 10, 516 - 521. 
National Committee for Clinical Laboratory Standards, 2008. Methods for dilution antimicrobial susceptibility tests for bacteria that grow aerobically; Document M07A8.CLSI, Wayne, PA.

Neuwinger, N.D., 1966. African Traditional Medicine. 1st Edition, Medpharm Scientific Publishers, Stuttgart.

Pallant, C.A., 2010. Bioactivity of the alkaloidal fraction of Tabernaemontana elegans (Stapf.). MSc thesis, University of Pretoria, Pretoria.

Pallant, C.A., Steenkamp, V., 2008. In vitro bioactivity of Venda medicinal plants used in the treatment of respiratory conditions. Human and Experimental Toxicology $27,859-866$.

Pereira, C.G., Marques, M.O.M., Barreto, A.S., Siani, A.C., Fernandes E.C., Meireles, M.A.A., 2004. Extraction of indole alkaloids from Tabernaemontana catharinensis using supercritical $\mathrm{CO}_{2}$ plus ethanol: An evaluation of the process variables and the raw material origin. Journal of Supercritical Fluids $30,51-61$.

Pereira, C.G., Leal, P.F., Sato, D.N., Meireles, M.A.A., 2005. Antioxidant and antimycobacterial activities of Tabernaemontana catharinensis extracts obtained by supercritical $\mathrm{CO}_{2}$ plus cosolvent. Journal of Medicinal Food 8, $533-538$. 
Rastogi, N., Abaul, J., Goh, K.S., Devallois, A., Philogène, E., Bourgeois, P., 1998. Antimycobacterial activity of chemically defined substances from the Carribbean flora in Guadelope. FEMS Immunology \& Medical Microbiology 20, 267 - 273.

Ruttoh, E.K., Tarus, P.K., Bii, C.C., Machocho, A.K., Karimi, L.K., Okemo, P.O., 2009. Antibacterial activity of Apocynaceae extracts and MIC of Tabernaemontana angulate stem organic extract. African Journal of Traditional, Complementary and Alternative Medicines 6, $186-194$.

Salgado, C.D., Farr, B.M., Calfee D.P., 2003. Community-acquired Methicillinresistant Staphylococcus aureus: A meta-analysis of prevalence and risk-factors. Clinical Infectious Diseases 36, 131 - 139.

Sefton, A.M., 2002. Mechanisms of antimicrobial resistance: Their clinical relevance in the new millennium. Drugs 62, $557-566$.

Siddiqi, S.H., Libonati, J.P., Middlebrook, G., 1981. Evaluation of a rapid radiometric method for drug susceptibility testing of Mycobacterium tuberculosis. Journal of Clinical Microbiology 13, $908-913$.

Stahl, E., 1969. Thin layer chromatography. $2^{\text {nd }}$ Edition, Springer-Verlag, Berlin. 
Steenkamp, V., Fernandes, A.C., Van Rensberg, C.E.J., 2007. Screening of Venda medicinal plants for antifungal activity against Candida albicans. South African Journal of Botany 73, $256-258$.

Thind, T.S., Agrawa, S.K., Saxena, A.K., Arora, S., 2008. Studies on cytotoxic, hydroxyl-radical scavenging and topoisomerase inhibitory activities of extracts of Tabernaemontana divericata(L.)R.br. ex. Roem.and Schult. Food and Chemical Toxicology 46, $2922-2927$.

Van Beek, T.A., Deelder, A.M., Verpoorte, R., Baerheim Svendson, A., 1984. Antimicrobial, antiamoebic and antiviral screening of some Tabernaemontana species. Planta Medica 50, 180 - 185.

Van Beek, T.A., Verpoorte, R., Baerheim Svendson, A., 1985. Antimicrobially active alkaloids from Tabernaemontana chippii. Journal of Natural Products 48, $400-423$.

Van der Heijden, R., Brouwer, R.L., Verpoorte, R., 1986. Indole alkaloids from Tabernaemontana elegans. Planta Medica 2, 144 - 147.

Watt, J.M., Breyer-Brandwijk, M.G., 1962. The medicinal and poisonous plants of Southern and Eastern Africa. $2^{\text {nd }}$ Edition, Livingstone, London. 
Weniger, B., Robledo, S., Arango, G.J., Deharo, E., Aragòn, R., Muñoz, V., Callapa J., Lobstein A., Anton R., 2001. Antiprotozoal activities of Colombian plants. Journal of Ethnopharmacology 78, $193-200$.

World Health Organisation, 2010a. Tuberculosis. World Health Organisation, Geneva.

World Health Organisation, 2010b. Multidrug and extensively drug-resistant TB (M/XDR-TB): 2010 Global report on surveillance and response. World Health Organisation, Geneva.

You, M., Ma, X., Mukherjee, R., Farnsworth, N.R., Cordell, G.A., Kinghorn, A.D.,Pezzuto, J.M., 1994. Indole alkaloids from Peschiera laeta that enhances vinblastine-mediated cytotoxicity with multidrug-resistant cells. Journal of Natural Products $57,1517-1522$.

Zhu, J-P., Guggisberg, A., Kalt-Hadamowsky, M., Hesse., M., 1990. Chemotaxonomic study of the genus Tabernaemontana (Apocynaceae) based on their indole alkaloid content. Plant Systematics and Evolution 172, 13 - 34. 


\section{Legends to Figure and Tables}

\section{Figure}

Figure 1. GS-MS total ion chromatogram of the alkaloidal fraction.

\section{Tables}

Table 1. MIC and MBC values obtained in the broth micro-dilution assay.

Table 2. IC $\mathrm{I}_{50}$ values obtained in the MTT and Neutral Red uptake cytotoxicity assays. 
Figure 1 GS-MS total ion chromatogram of the alkaloidal fraction

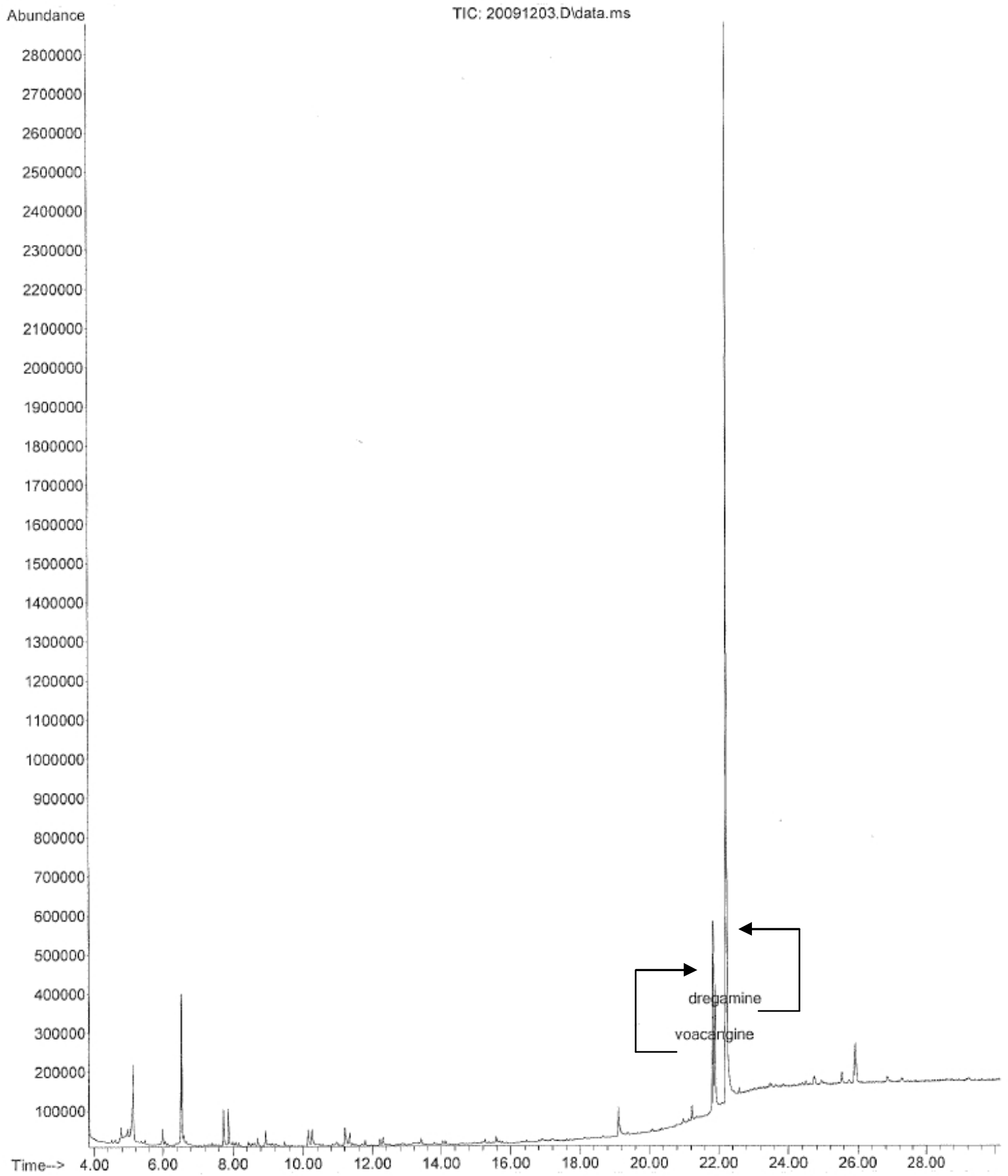


Table 1 MIC and MBC values obtained in the broth micro-dilution assay.

\begin{tabular}{|c|c|c|c|c|c|c|}
\hline \multirow[t]{2}{*}{ Micro-organism } & \multicolumn{2}{|c|}{$\begin{array}{c}\text { Crude extract } \\
(\mu \mathrm{g} / \mathrm{ml})\end{array}$} & \multicolumn{2}{|c|}{$\begin{array}{c}\text { Alkaloidal fraction } \\
(\mu \mathrm{g} / \mathrm{ml})\end{array}$} & \multicolumn{2}{|c|}{$\begin{array}{c}\text { Antibiotic control } \\
(\mu \mathrm{g} / \mathrm{ml})^{\mathrm{a}}\end{array}$} \\
\hline & MIC & MBC & $\underline{\mathrm{MIC}}$ & $\underline{\text { MBC }}$ & MIC & MBC \\
\hline \multicolumn{7}{|l|}{ Gram-positive } \\
\hline E. faecalis (ATCC 29212) & 128 & 512 & 64 & 256 & 0.50 & 1.00 \\
\hline S. aureus (ATCC 12600) & 128 & 128 & 32 & 64 & 0.06 & 0.06 \\
\hline S. aureus (NHLS 363) & 128 & 128 & 32 & 64 & $>2$ & NA \\
\hline E. coli (ATCC 35218) & $>1024$ & NA & 512 & 512 & 0.13 & 0.13 \\
\hline K. pneumonia (ATCC 13883) & $>1024$ & $\mathrm{NA}$ & $>512$ & NA & 0.13 & 0.13 \\
\hline P. aeruginosa (ATCC 9027) & $>1024$ & NA & $>512$ & $\mathrm{NA}$ & 0.50 & 0.50 \\
\hline \multicolumn{7}{|l|}{ Mycobacteria } \\
\hline M. smegmatis (ATCC 14468) & 256 & 1024 & 32 & 128 & 0.50 & 0.50 \\
\hline M. tuberculosis (ATCC 25177) & 128 & ND & 32 & ND & 0.10 & ND \\
\hline
\end{tabular}

${ }^{a}$ Antibiotic for Gram-positive bacteria - ampicillin; Antibiotic for Gram-negative bacteria- ciprofloxacin; Antibiotic for M. smegmatis ciprofloxacin; Antibiotic for M. tuberculosis - isoniazid.

${ }^{\mathrm{b}}$ Clinical isolate of $S$. aureus- resistant to ampicillin, erythromycin, clindamycin and oxacillin

${ }^{\circ}$ Clinical isolate of M. tuberculosis - resistant to isoniazid

NA: No activity

ND: Not determined 
Table 2 $\mathrm{IC}_{50}$ values obtained in the MTT and Neutral Red uptake cytotoxicity assays.

\begin{tabular}{|c|c|c|c|c|c|c|}
\hline \multirow[t]{2}{*}{ Cell line } & \multicolumn{6}{|c|}{$\mathrm{IC}_{50}$} \\
\hline & \multicolumn{3}{|c|}{ MTT assay } & \multicolumn{3}{|c|}{ Neutral red uptake assay } \\
\hline \multicolumn{7}{|l|}{ Primary cell cultures } \\
\hline Resting lymphocytes & $4.52 \pm 3.20$ & $1.75 \pm 1.35$ & 0.006 & $19.27 \pm 8.43$ & $4.35 \pm 0.58$ & 0.004 \\
\hline PHA-stimulated lymphocytes & $11.77 \pm 4.20$ & $1.67 \pm 1.96$ & 0.006 & $9.05 \pm 5.10$ & $2.30 \pm 1.96$ & 0.005 \\
\hline \multicolumn{7}{|l|}{ Cell lines } \\
\hline HepG2 hepatocytes & $5.81 \pm 4.85$ & $1.11 \pm 0.49$ & 0.005 & $1.93 \pm 0.29$ & $1.27 \pm 0.26$ & 0.003 \\
\hline THP-1 macrophages & $16.77 \pm 9.56$ & $9.73 \pm 4.10$ & 0.01 & $8.10 \pm 2.92$ & $8.23 \pm 0.88$ & 0.012 \\
\hline
\end{tabular}

